\title{
Woody plants structure and composition in Burkina Faso Sahel: case study in Kékénéné village
}

\author{
Pounyala Awa OUOBA* and Dapola Evariste Constant DA
}

\author{
Dynamic of Spaces and Societies Lab., Department of geography, University Ouagal Pr Joseph Ki-Zerbo, 03 \\ BP 7021 Ouaga 03, Ouagadougou, Burkina Faso. \\ *Corresponding author; E-mail: mpounyala@gmail.com; Tel: +226 70224579
}

\begin{abstract}
Understanding woody vegetation composition and structure is important for leading management decisions in the Sahelian vulnerable zones. The objective of the study was to better knowledge woody vegetation structure and richness in natural vegetation and cropland. The study area is Kékénéné village located in Soum province, surroundings Djibo in northern Burkina Faso. In total 54 sample plots were surveyed by means of a botanical inventory of woody vegetation species. All trees $\geq 10 \mathrm{~cm}$ dbh were measured. The vegetation structure pattern analyzed were diameter at breast height ( $\mathrm{dbh}$ ), basal area, relative dominance, and relative density, Importance Value Index (IVI) and Family Importance Value (FIV). In total 658 trees recorded was belonging to 21 species, 9 families in natural vegetation and 11 species, 5 families in cropland. Tree density was $15.7 \mathrm{stems} / \mathrm{ha}$ and $3.7 / \mathrm{ha}$ respectively in natural vegetation and cropland. Tree basal area was $0.54 \mathrm{~m}^{2} \mathrm{ha}^{-1}$ for cropland and $0.35 \mathrm{~m}^{2} \mathrm{ha}^{-1}$ in natural vegetation with a mean dbh of $3.5 \mathrm{~cm}$ for the two occupation types. The most importance family according to FIV was Balanitaceae in cropland and Combretaceae in natural vegetation. The Sorensen' similarity coefficient of family in the two landscapes is lowest than 0.5 which means that the similarities in species family are low between the two occupation types. In natural vegetation, Anogeisus leiocarpus and Balanites aegyptiaca were the most important species in relation to IVI, while in cropland Balanites aegyptiaca, Acacia senegal and Acacia seyal were the most important species. Results reveal an abundance of Balanites aegyptiaca in both cropland and natural vegetation in the study site. Given its high socio-economic value in this region, this tree deserves to be more valued in a perspective of management and sustainable use in Kékénéné village.
\end{abstract}

(C) 2019 International Formulae Group. All rights reserved

Keywords: Composition and structure, woody species, management, Sahel ecosystems, Burkina Faso.

\section{INTRODUCTION}

Vegetation management is carried out with varying objectives in mind, one of which is biodiversity conservation. Woody vegetation affects ecosystem processes and contribute to livelihoods, as it improves soils nutrient and water availability for agricultural crop and pasture and influences soil water evapotranspiration, soil stability and erosion, soil carbon as well (Müller, 2008; Félix et al., 2015). The species generate multiple provisioning ecosystem services such as medicinal uses, contribution to fodder for livestock and importance for human nutrition (Ganaba et al., 2005; Gouwakinnou et al., 2011; Sarr et al., 2013). Furthermore, hardwooded trees in particular, are used for timber in construction as well as for firewood and charcoal production. These Services and theirs cultural values play an important role in the conservation (Haglund et al., 2011; Sinare et al., 2015; Sacande et al., 2016; Etongo et al., 2017). 
Understanding woody vegetation composition and structure is important for guiding management decisions in the Sahelian vulnerable zones (Mahamat-Saleh et al., 2013; Mahamat-Saleh et al., 2015; Garba et al., 2017). Conservation is imperative since the ecological treats are still persistent (Vincke et al., 2010; Kabore et al., 2013; Elfaig et al., 2015). In Burkina Faso, many studies highlighted several threats on Sahelian ecosystems, as natural factors influencing wind erosion, water resource scarcity explained by the regression of the plant species (Maranz, 2009; Gonzalez et al., 2012). Some results underlined that the degradation of land cover and trees declining in the Sahel zones are due to human high pressure on the vegetation and overgrazing (Ozer et al., 2010) while recently, others authors found that in semi-arid Sahel, farmland management promotes woody cover around villages (Brandt et al., 2018).

Recent findings based on satellite images analyses reveal an increasing trend of biomass in some Sahelian areas of West Africa, known as the re-greening phenomenon (Brandt et al., 2017; Leroux et al., 2017). This implies an increase in the vegetation density, in total contrast with the general narration of the persistence of ecosystem degradation, woody plants declining and increasing drought-resistant species found in literature (Herrmann et al., 2013; Kadeba et al., 2015; Hänke et al., 2016; Rasmussen et al., 2016). Thus, the increase in woody biomass did not always reflect on biodiversity woody species increasing in abundance (Brandt et al., 2015). Therefore, it is useful to further make based field investigations on tree cover in terms of vegetation structure and species composition, in order to support the strategy of biodiversity conservation. The main objective of the study was to explore woody vegetation structure and species richness in contrasted cropland and natural vegetation in Sahelian zones of Burkina Faso.

\section{MATERIALS AND METHODS Area description}

The study was conducted in the Sahelian region of Burkina Faso in the Kékénéné village located in Soum province (Djibo town) (Figure 1). The study area lies approximately between latitude $14^{\circ} 23^{\prime}$ to 14 ${ }^{\circ} 25^{\prime} \mathrm{N}$ and longitude $1{ }^{\circ} 01$ ' to $1^{\circ} 04^{\prime} \mathrm{W}$ covering about $480 \mathrm{~km}^{2}$. This area is characterized by an arid climate, with a unimodal rainfall pattern, marked by a fluctuation of dry season from November to April and a rainy season, from May to October. The average annual rainfall of the area is about $400 \mathrm{~mm} / \mathrm{year}$ for the period 1981-2018. The average annual temperature of the Dori Station is around $30{ }^{\circ} \mathrm{C}$.

The Kékénéné landscape is located in the northern Sahelian phytogeographical area, characterized by vegetation dominated by steppe shrubby vegetation (Thiombiano et al., 2010) composed mainly of Combretum glutinosum, Balanites aegyptiaca, Acacia seyal, and Acacia raddiana. The herbaceous carpet consists mainly of Schoenfeldia gracilis, Cenchrus biflorus, and Aristida spp. The relief is mainly a vast peneplain with some massifs and buttes battled in places. The dominant soils are sub-modal brown soils with a sandy-loam texture and sometimes gravelly cover.

The population of Kékénéné is 1665 inhabitants in 2006 according to the National Institute of Statistics and Demography INSD - (INSD, 2009). The annual rate of change in density between 1996 and 2006 is $4.15 \%$. The study area is farming and grazing zone, with a population consisting mainly of Mossi migrants and Fulcé natives. Livestock is also important. The livestock is mainly composed of cattle, goats and sheep. The breeding is extensive and mainly sedentary type.

\section{Ground data collection}

A stratified systematic design was applied along transects on the land use map of Kékénéné. The land use map of the recent period (2015) from numerical classification was used as a background to layout the plots along transects in each main land use unit. Square plot of $100 \times 100$ meters (e.g. 1 ha) were used for the ecological description and the measurements of tree species. The GPS was used during the field work to find the plots. In each plots, $\mathrm{dbh} \geq 2.5 \mathrm{~cm}$ and height above $1.5 \mathrm{~m}$ were measured for all individual trees of that range. The identification of all 
trees in the inventory follows the nomenclature of Arbonnier (2009).

The floristic composition and structure was examined by Importance Value Index (IVI), which is the sum of relative density, relative dominance and relative frequency of a species. Importance Value Index is an important parameter that indicates the ecological significance of species in a given ecosystem. Species with high IVI values are regarded as more important than those with low IVI values. The IVI values are also used in conservation programs, where species with low IVI values are prioritized for conservation and those with high IVI values need monitoring management (Neelo et al., 2015). For all families, we determined Family Importance Value (FIV), which is the sum of relative density, relative dominance and relative diversity, where relative diversity is number of species of family/total number of species. The relative density $=$ (number of individuals of a species /total number of individuals) $\times 100$; the relative dominance $=$ (total basal area for a species/total basal area of all species) x100 and the relative frequency $=$ (frequency of a species/sum of all species) $\mathrm{x} 100$. The frequency is defined as the number of occurrence of the species within a plot. The theoretical range of relative dominance, relative frequency, relative density, and relative diversity is $0-100 \%$; therefore the IVI and FIV may be between 0 and $300 \%$. For the structural characteristics, the stem density, basal area, and diameter were computed for each plots; the average was calculated for the vegetation unit for all individual of $2.5 \mathrm{~cm}$ dbh.

To compare family diversity between occupation types, Sorensen's similarity coefficient (Krebs, 1999) was calculated using the similarity in species composition of seedlings in cropland and natural vegetation by using the following formula:

$$
\text { Ss }=2 \mathrm{a} /(2 \mathrm{a}+\mathbf{b}+\mathbf{c})
$$

Where, $\quad \mathbf{S}_{\mathrm{s}}=$ Sorensen's similarity coefficient, $\mathbf{a}=$ number of species with seedlings present in cropland and natural vegetation, $\mathbf{b}=$ number of species with seedlings exclusively present in cropland, and c $=$ number of species with seedlings exclusively present in natural vegetation. Sorensen's coefficient has a range between zero (no species in common) and 1 (complete similarity).

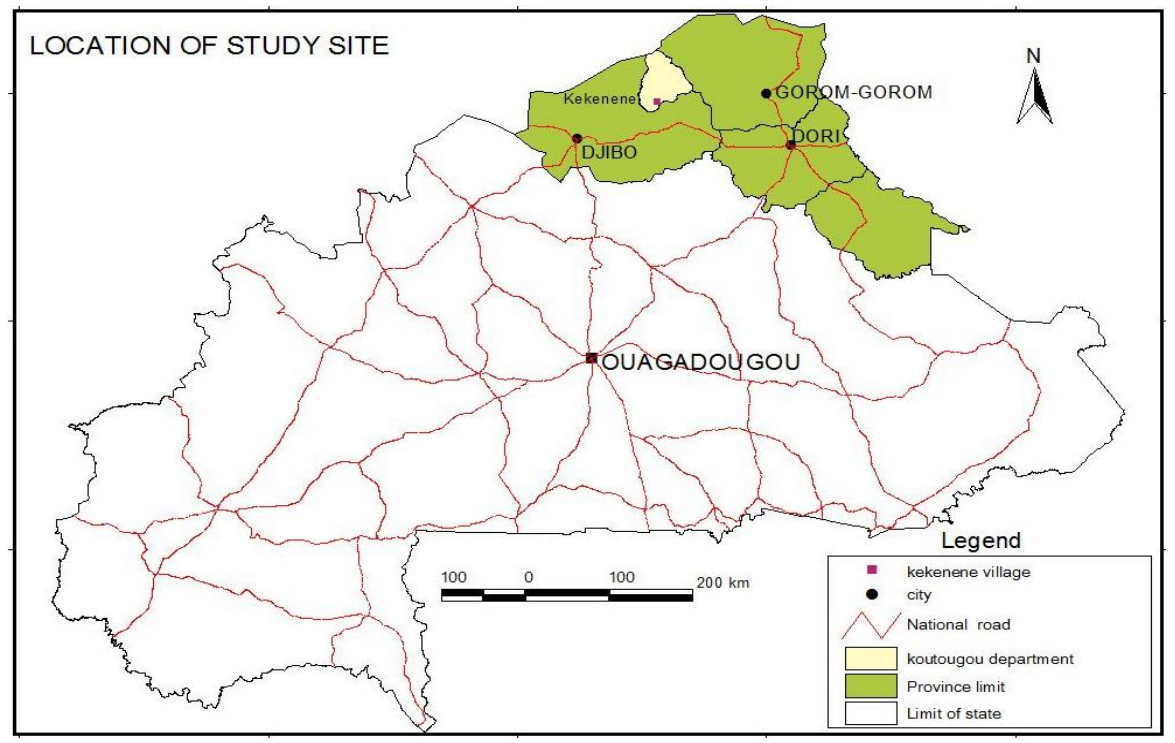

Figure 1: Location of Kékénéné in Djibo, Soum Province. 


\section{RESULTS}

\section{Tree species richness and similarity in the two occupation types}

The total number of trees recorded was 658 belonging to 21 species, 9 families in natural vegetation and 11 species, 5 families in cropland (Table 1). Tree basal area was $0.54 \mathrm{~m}^{2} \mathrm{ha}^{-1}$ for Cropland and $0.35 \mathrm{~m}^{2} \mathrm{ha}^{-1}$ in natural vegetation with a mean dbh of $3.5 \mathrm{~cm}$ for two occupation types.

In natural vegetation, five families were represented by a single species each; two families were represented by 4 species each, one family was represented by 6 species. In cropland, two families were represented by a single species each and one family was represented by four species (Table 2). The most diverse family was Combretaceae, with $23.19 \%$ of the total number of species, followed by Balanitaceae (20.29\%) in natural vegetation (Table 2). In cropland the most diverse families were Mimosaceae (33.33\%) and Balanitaceae (25\%). Combretaceae family had the highest relative density (63.04) in natural vegetation, while Balanitaceae (56.14) had in cropland (Table 2). The family with the highest relative dominance was Combretaceae (55.00) in natural vegetation. In cropland, it was Balanitaceae with a relative dominance of 42.47. The highest family importance value (FIV) observed was 141.22 for Combretaceae in natural vegetation and 123.61 for Balanitaceae in cropland.

The highest similarity in family composition recorded between cropland and natural vegetation was 0.42 . Four of the families, namely Capparaceae, Anacardiaceae,
Asclepiadaceae and Rubiaceae were exclusively found in natural vegetation. The similarity coefficients in families of the two occupation types is lowest than 0.5 (Table 3).

\section{Vegetation structure of the occupation types}

The analysis of the results shows that the plant species Balanites aegyptiaca is most frequent in natural vegetation and cropland with respectively the relative frequency of 20.29 and 25.00 .

The highest relative dominance encountered in the natural vegetation was 45.93 for Anogeissus leiocarpus which yields an absolute basal area of $5.01 \mathrm{~m}^{2} \mathrm{ha}^{-1}$. In the cropland, the dominant species was Acacia Senegal with a relative dominance of 6.72 and a basal area of $0.096 \mathrm{~m}^{2} \mathrm{ha}^{-1}$ (Table 4).

In terms of density, Combretum micranthum and Balanites aegyptiaca are highest in natural vegetation with respectively a relative density of 42.09 and 16.84 . This species could be considered as the most abundant in the study area. Acacia seyal and Acacia Senegal are the most abundant species in cropland with a relative density of 19.75 for both.

The highest important value index (IVI) recorded in natural vegetation was 58.71 for Anogeisus leiocarpus, followed by Balanites aegyptiaca and Combretum micranthum with an IVI of 57.33 and 51.64, respectively. In cropland, Balanites aegyptiaca had the highest important value index of 43.11 (Table 4). 
Table 1: Summary of vegetation composition and structure of study area.

\begin{tabular}{|c|c|c|c|c|c|c|c|c|}
\hline \multirow[t]{2}{*}{$\begin{array}{c}\text { Occupation } \\
\text { type }\end{array}$} & \multirow[t]{2}{*}{$\begin{array}{l}\text { No. Sample } \\
\text { plots }\end{array}$} & \multirow[t]{2}{*}{$\begin{array}{c}\text { No. } \\
\text { stem }\end{array}$} & \multirow[t]{2}{*}{$\begin{array}{l}\text { No. stems } \\
\text { per hectare }\end{array}$} & \multicolumn{3}{|c|}{ Richness } & \multirow[t]{2}{*}{$\begin{array}{l}\text { Average } \\
\text { DBH }\end{array}$} & \multirow[t]{2}{*}{ Basal area } \\
\hline & & & & $\begin{array}{c}\text { No. } \\
\text { Family }\end{array}$ & $\begin{array}{c}\text { No. } \\
\text { Genera }\end{array}$ & $\begin{array}{c}\text { No. } \\
\text { Species }\end{array}$ & & \\
\hline $\begin{array}{c}\text { Natural } \\
\text { vegetation }\end{array}$ & 31 & 487 & 15.7 & 9 & 14 & 21 & $3.5(\mathrm{~cm})$ & $0.35\left(\mathrm{~m}^{2} / \mathrm{ha}\right)$ \\
\hline Cropland & 23 & 171 & 3.7 & 5 & 9 & 11 & $3.5(\mathrm{~cm})$ & $0.54\left(\mathrm{~m}^{2} / \mathrm{ha}\right)$ \\
\hline
\end{tabular}

Table 2: FIV index for the two occupation types. ReDiv = relative diversity; ReDom = relative dominance; ReDens = relative density; FIV = family importance value.

\begin{tabular}{l|llllll}
\hline Occupation type & Family & $\mathbf{N}^{\circ}$ species & ReDiv & ReDom & ReDens & FIV \\
\hline \multirow{5}{*}{ Natural vegetation } & Combretaceae & 4 & $\mathbf{2 3 . 1 9}$ & $\mathbf{5 5 . 0 0}$ & $\mathbf{6 3 . 0 4}$ & $\mathbf{1 4 1 . 2 2}$ \\
& Balanitaceae & 1 & 20.29 & 20.20 & 16.84 & 57.33 \\
& Caesalpiniaceae & 4 & 18.84 & 15.25 & 8.42 & 42.51 \\
& Mimosaceae & 6 & 15.94 & 8.10 & 8.01 & 32.05 \\
& Capparaceae & 2 & 11.59 & 1.26 & 2.05 & 14.91 \\
& Rhamnaceae & 1 & 5.80 & 0.06 & 0.62 & 6.48 \\
& Anacardiaceae & 1 & 1.45 & 0.10 & 0.41 & 1.96 \\
& Asclepiadaceae & 1 & 1.45 & 0.00 & 0.41 & 1.86 \\
& Rubiaceae & 1 & 1.45 & 0.05 & 0.21 & 1.70 \\
& & & & & & FIV \\
\hline \multirow{5}{*}{ Cropland } & Family & $\mathbf{N}^{\circ}$ species & ReDiv & Re Dom & ReDens & Fin \\
& Balanitaceae & 1 & 25.00 & $\mathbf{4 2 . 4 7}$ & $\mathbf{5 6 . 1 4}$ & $\mathbf{1 2 3 . 6 1}$ \\
& Mimosaceae & 4 & $\mathbf{3 3 . 3 3}$ & 10.89 & 15.79 & 60.01 \\
& Combretaceae & 3 & 16.67 & 32.01 & 11.11 & 59.79 \\
& Rhamnaceae & 1 & 12.50 & 7.11 & 8.77 & 28.38 \\
& Caesalpiniaceae & 2 & 12.50 & 7.51 & 8.19 & 28.20 \\
\hline
\end{tabular}

Table 3: Sorensen's similarity coefficient in family for the two occupation types.

\begin{tabular}{l|cc}
\hline Occupation type & Natural vegetation & Cropland \\
\hline Natural vegetation & - & - \\
Cropland & 0.42 & - \\
\hline
\end{tabular}


Table 4: List of species according to IVI in occupation types.

\begin{tabular}{|c|c|c|c|c|c|c|}
\hline Occupation type & Species & $B A m^{2} / h a$ & ReDens & ReFreq & ReDom & $I V I$ \\
\hline \multirow{21}{*}{$\begin{array}{l}\text { Natural } \\
\text { vegetation }\end{array}$} & Anogeisus leiocarpus & 5.01 & 6.98 & 5.80 & 45.93 & 58.71 \\
\hline & Balanites aegyptiaca & 2.20 & 16.84 & 20.29 & 20.20 & $\mathbf{5 7 . 3 3}$ \\
\hline & Combretum micranthum & 0.25 & 42.09 & 7.25 & 2.30 & 51.64 \\
\hline & Pterocarpus lucens & 1.63 & 6.98 & 14.49 & 14.97 & 36.44 \\
\hline & Combretum glutinosum & 0.46 & 12.32 & 8.70 & 4.24 & 25.26 \\
\hline & Acacia seyal & 0.43 & 2.87 & 4.35 & 3.96 & 11.18 \\
\hline & Boscia angustifolia & 0.14 & 1.23 & 7.25 & 1.24 & 9.72 \\
\hline & Acacia raddiana & 0.03 & 2.67 & 5.80 & 0.28 & 8.74 \\
\hline & Ziziphus mauritiana & 0.01 & 0.62 & 5.80 & 0.06 & 6.48 \\
\hline & Acacia laeta & 0.38 & 1.23 & 1.45 & 3.49 & 6.17 \\
\hline & Mitragina Inermis & 0.28 & 1.64 & 1.45 & 2.53 & 5.62 \\
\hline & Piliostigma thonningii & 0.02 & 1.03 & 2.90 & 0.18 & 4.10 \\
\hline & Boscia senegalensis & 0.00 & 0.82 & 2.90 & 0.02 & 3.74 \\
\hline & Acacia senegal & 0.04 & 0.62 & 1.45 & 0.35 & 2.41 \\
\hline & Sclerocarya birrea & 0.01 & 0.41 & 1.45 & 0.10 & 1.96 \\
\hline & Acacia siberiana & 0.00 & 0.41 & 1.45 & 0.01 & 1.87 \\
\hline & Calotropis procera & 0.00 & 0.41 & 1.45 & 0.00 & 1.86 \\
\hline & Piliostigma reticulatum & 0.01 & 0.21 & 1.45 & 0.06 & 1.71 \\
\hline & Bauhinia refuscens & 0.01 & 0.21 & 1.45 & 0.05 & 1.70 \\
\hline & Feretia apotanthera & 0.01 & 0.21 & 1.45 & 0.05 & 1.70 \\
\hline & Acacia pennata & 0.00 & 0.21 & 1.45 & 0.02 & 1.67 \\
\hline \multirow{12}{*}{ Cropland } & Species & $B A m^{2} / h a$ & ReDens & ReFreq & ReDom & $I V I$ \\
\hline & Balanites aegyptiaca & 0.000 & 14.62 & 25.00 & 3.49 & 43.11 \\
\hline & Acacia senegal & 0.096 & 15.79 & 12.50 & 6.72 & 35.01 \\
\hline & Acacia seyal & 0.031 & 15.79 & 14.58 & 4.30 & 34.67 \\
\hline & Ziziphus mauritiana & 0.000 & 12.28 & 12.50 & 3.45 & 28.23 \\
\hline & Piliostigma reticulatum & 0.000 & 14.62 & 8.33 & 3.48 & 26.43 \\
\hline & Combretum aculeatum & 0.001 & 14.04 & 6.25 & 3.47 & 23.75 \\
\hline & Anogeisus leiocarpus & 0.018 & 7.02 & 10.42 & 3.44 & 20.87 \\
\hline & Acacia raddiana & 0.000 & 3.51 & 4.17 & 2.98 & 10.66 \\
\hline & Pterocarpus lucens & 0.018 & 1.17 & 4.17 & 2.92 & 8.26 \\
\hline & Combretum glutinosum & 0.096 & 0.58 & 0.00 & 2.47 & 3.06 \\
\hline & Acacia pennata & 0.002 & 0.58 & 2.08 & 0.05 & 2.72 \\
\hline
\end{tabular}




\section{DISCUSSION}

In this present study, the result revealed that the maximum species richness and abundance were comparable to those in some areas in West Africa Sahel (Diouf et al., 2002; Charahabil et al., 2013; Sarr et al., 2013).

The highest family importance value (FIV) observed was 141.22 for Combretaceae in natural vegetation and 123.61 for Balanitaceae in cropland. The high presence of Combretaceae in natural vegetation is due to the fact that some species of that family are able to resist to some perturbations. The similarity in family composition recorded between cropland and natural vegetation is lowest than 0.5 which means that the floristic composition is different between the two occupation types.

Although the number of plots inventoried did not allow for statistical comparisons, some tendencies in diversity and density can be observed in Table 2 . Of the two occupation types, natural vegetation exhibited the highest number of families and species which were more than 2 times higher than that recorded in cropland. The flora of natural vegetation is more diversified than that of cultivated ecosystems. This is because some plant species are cut when new fields are being prepared (Bassene et al., 2014). Combretaceae family had the highest relative density (63.04) in natural vegetation, while Balanitaceae (56.14) had in cropland. The most diverse family was Combretaceae followed by Balanitaceae in natural vegetation. In cropland the most diverse families were Mimosaceae and Balanitaceae. The relatively low diversity between families at both landscape types can be attributed to the habitat conditions and species characteristics.

In natural vegetation, Anogeisus leiocarpus, Balanites aegyptiaca and Combretum micranthum can be considered the most ecologically important woody species, especially Balanites aegyptiaca with IVI values of more than 20 contributed by its high value of density, frequency and dominance. In cropland, Balanites aegyptiaca with an important value index of 43.11 is considered the most ecologically important woody species.

In terms of density, Combretum micranthum and Balanites aegyptiaca are highest in natural vegetation with respectively a relative density of 42.09 and 16.84 . Acacia seyal and Acacia Senegal are the most abundant species in cropland with a relative density of 19.75 for both. The domination of Acacia species, which are indicative of heavy grazing is rational with the fact that cropland is used as a cattle post by people living in the village during dry season. Thus, seed scattering, which is known to be facilitated by ruminants that usually browse Acacia species, could be responsible of their relatively high number and density recorded.

In terms of relative frequency, the results also show that Balanites aegyptiaca is most frequent in natural vegetation and cropland (respectively 20.29 and 25.00). This species is widespread in the study site and is a thorny shrub characteristic of Africa's drylands. This supports the observation of Sop et al. (2011). Indeed, the high frequency of this species testifies to its resistance to the drought that has raged in this Sahelian zone since the 1970s. These results corroborate those of Ndiaye et al. (2013) which stipulate that a modification of the flora in the sense of an invasion of species considered desert is possible following a rapid increase in erosion (hence aridity) on a larger scale. Herrmann and Tappan (2013) also noticed a shift of Sahelian species towards more arid-tolerant, since 1983.

Balanites aegyptiaca is an endemic sahelian species with a strong colonizing ability that ensure stable populations for this species even though regeneration happens rarely (Müller, 2008; Sop et al., 2011). In many studies carried out in some regions of West Africa Sahel, Balanites aegyptiaca, were mentioned exhibiting moderate survival rates (Wade et al., 2018) and also having vastly increased in number, to be the dominant species. This has been observed at Oursi in northern BF (Maranz, 2009). Brandt et al. (2017) also found a rapid growth of Balanites 
aegyptiaca between 2000 and 2013 in Senegalese Sahel. Balanites aegyptiaca has a coppicing and resprouting abilities that allow this specie to sustain its persistence in that semi-arid region (Hänke et al., 2016). But some concerns are raised about the population status of species in Sudan where disappearance of Balanites aegyptiaca which was abundantly existed and widely spread in the study area becomes very few (Elfaig et al., 2015). Indeed, woody vegetation paid a tribute to drought in Sahel areas but also to human disturbances. The study area has been exposed not only to overgrazing, but also exploitation by rain-fed agriculture. Anthropogenic practices such as logging or cutting trees do not systematically lead to a decline in species diversity and abundance. The reasons for low variation in floristic composition of the two occupation types could be due to moderate anthropogenic disturbances and exploitation of some species, especially in cropland. In the study area, croplands are used as a cattle ranch during dry season by the local people. Therefore, due to the lack of herbaceous at that season some species of Mimosaceae and Balanitaceae are preserved and managed by pruning and use as fodder. The high frequency of Balanites aegyptiaca in cropland could be due to low anthropogenic pressure (good practices of harvesting / exploitation). In this village, this specie is only kept for breeding contrary to the surrounding villages in the province of Seno, Oudalan, and Soum in the same ecological zone, where the population namely Foulbe gaobé, Foulbé djelgobé, Sonraï, Bella, Touareg exploit Balanites aegyptiaca for many uses such as crafts (camel saddle, stool, pestle, mortar, bowl, spoon, spatula, toothpick) and food supply (Lykke et al., 2004; Ganaba et al., 2005; Sop et al., 2012). This could be explained by the ethnic difference because the population of Kékénéné is mainly constituted of Mossi, who are migrants and settled in the village especially for agriculture, gold-rush and breeding. The population of Kékénéné has an important traditional vegetation management systems and practices, which have contributed a lot for the maintenance of the vegetation resources by the involvement of government bodies. They had important practices that helped for the maintenance of the vegetation in croplands. They retain indigenous trees like Balanites aegyptiaca in the farmlands as fodder for livestock. Those management practices in semi-arid Sahel promote woody cover in farmland around villages but also in bush cropland. That is supported in literature (Haglund et al., 2011; Brandt et al., 2018).

\section{Conclusion}

The work presented here provides evidence that species belonging to the family of Combretaceae, Mimosaceae and Balanitaceae have a high frequency and abundance in the woody areas of the Sahelian zones of Burkina Faso. A better adaptation of these species to the climatic conditions added to the preservation of Balanites aegyptiaca in cropland for breeding, would be the causes of this tendency. Policy makers and development agencies should more address and integrate local people's species preferences and conservation priorities in their global strategy for poverty relief. This Balanites specie need to be better valued in the village site due to its importance for the craft and food use of seeds and fruit encountered elsewhere in the Sahel region. The environmental education programmes at local level-organized as part of capacity building for cattle-breeder and farmers should provide a platform for sharing traditional knowledge about species use elsewhere in Burkina Faso. This could improve the resilience of this Sahelian population. However, there is at the same time, a threat that could weigh on species in this area due to overexploitation and the recent massive arrival and settlement of refugees from neighboring countries (Mali) with their herds. Therefore, the regulation of grazing activities in the area represents an indispensable component for ecosystems conservation. The maintenance of ecosystem balance in the region of Sahel and the conservation of its ecosystems is very important for the survival and the development of rural communities, whose 
future is bound to the availability of natural resources. Monitoring is equally crucial. This includes tracking and reviewing vegetation structure to improve management and conservation strategies.

\section{COMPETING INTERESTS}

The authors declare that they have no competing interests.

\section{AUTHORS' CONTRIBUTIONS}

The first author collected the data in Kékénéné village and drafted the present manuscript. The others authors had carefully read and contributed to the present version of the manuscript.

\section{ACKNOWLEDGMENTS}

The authors are grateful to all people who contributed to data collection.

\section{REFERENCES}

Arbonnier M. 2009. Arbres, Arbustes et Lianes des Zones Sèches d'Afrique de l'Ouest (Troisième édition). QUAE MNHN: Paris. 573 p.

Bassene C, Mbaye MS, Camara AA, Kane A, Gueye M, Sylla SN, Sambou B, Noba K. 2014. La flore des systèmes agropastoraux de la Basse Casamance (Sénégal) : cas de la communauté rurale de Mlomp. Int. J. Biol. Chem. Sci., 8(5) : 2258-2273.

DOI: http://dx.doi.org/10.4314/ijbcs.v8i5.28

Brandt M, Mbow C, Diouf AA, Verger A, Samimi C, Fensholt R. 2015. Groundand satellite-based evidence of the biophysical mechanisms behind the greening Sahel. Global Change Biology, 21: $\quad 1610-1620 . \quad$ DOI: https://doi.org/10.1111/gcb.12807

Brandt M, Rasmussen K, Hiernaux $P$, Herrmann S, Tucker CJ, Tong X, Tian F, Mertz O, Kergoat L, Mbow C, David JL, Melocik KA, Dendoncker M, Vincke C, Fensholt R. 2018. Reduction of tree cover in West African woodlands and promotion in semi-arid farmlands. Nature Geoscience, 11: 328-333. DOI: https://doi.org/10.1038/s41561-0180092-x

Brandt M, Tappan G, Diouf AA, Beye G, Mbow C, Fensholt R. 2017. Woody Vegetation Die off and Regeneration in Response to Rainfall Variability in the West African Sahel. Remote Sens., 9(39): $1-21 . \quad$ DOI: https://doi.org/10.3390/rs9010039

Charahabil MM, Diallo A, Ngom D, Diop B, Akpo LE. 2013. Importance des Combretaceae dans des forêts communautaires de la zone soudanosahélienne au Sénégal. Sécheresse, 24: 3947.4 DOI: https://www.jle.com/10.1684/sec.2012.0 368

Diouf M, Akpo LE, Rocheteau A, Do F, Goudiaby V, Diagne AL. 2002. Dynamique du peuplement ligneux d'une végétation sahélienne au nordSénégal (Afrique de l'ouest). Journal des Sciences, 2(1): 1-10.

Elfaig AHI, Ibrahim HH, Egemi O, Mokhtar J. 2015. Environmental degradation in the Sahel: a study from western Sudanghubaysh area. International Journal of Current Research, 7(2): 12588-12596.

Etongo D, Djenontin INS, Kanninen M, Glover EK. 2017. Assessing use-values and relative importance of trees for livelihood values and their potentials for environmental protection in Southern Burkina Faso. Environment Development and Sustainability, 19(4): 1141-1166. DOI: https://doi.org/10.1007/s10668016-9787-6

Félix GF, Douzet JM, Ouédraogo M, Belliard $\mathrm{P}$, Lahmar R, Clermont-Dauphin C, Scholberg J, Tittonell P, Cournac L. 2015. Ecosystem services for West African farming families: the role of woody shrub mulch. 5th International Symposium for Farming Systems Design. Montpellier, France.

Ganaba S, Ouadba JM, Bognounou O. 2005. Exploitation traditionnelle des végétaux spontanés en région sahélienne du Burkina Faso. VertigO - La revue en sciences de l'environnement, 6(2): 14. 
DOI:

https://dx.doi.org/10.4000/vertigo.15131

Garba A, Djima IT, Abdou L, Mahamane A. 2017. Caractérisation de la végétation ligneuse du bassin versant de la Maggia dans la commune rurale de Bagaroua (région de Tahoua). Int. J. Biol. Chem. Sci., 11(2): 571-584, DOI: https://dx.doi.org/10.4314/ijbcs.v11i2.4

Gonzalez P, Tucker CJ, Sy H. 2012. Tree density and species decline in the African Sahel attributable to climate. Journal of Arid Environments, 78: 5564.

DOI:

https://doi.org/10.1016/j.jaridenv.2011.1 1.001

Gouwakinnou GN, Lykke AM, Assogbadjo AE, Sinsin B. 2011. Local knowledge, pattern and diversity of use of Sclerocarya birrea. Journal of Ethnobiology and Ethnomedicine, 7:8: 1-9. DOI: https://doi.org/10.1186/17464269-7-8

Haglund E, Ndjeunga J, Snook L, Pasternak D. 2011. Dry land tree management for improved household livelihoods: Farmer managed natural regeneration in Niger. Journal of Environmental Management, 92(7): 1696-1705. DOI: https://doi.org/10.1016/j.jenvman.2011.0 1.027

Hänke H, Börjeson L, Hylander K, EnforsKautsky E. 2016. Drought tolerant species dominate as rainfall and tree cover returns in the West African Sahel. Land Use Policy, 59: 111-120. DOI: http://dx.doi.org/10.1016/j.landusepol.20 16.08.023

Herrmann SM, Tappan GG. 2013. Vegetation impoverishment despite greening: A case study from central Senegal. Journal of Arid Environments, 90: 55-66. DOI: http://dx.doi.org/10.1016/j.jaridenv.2012 .10 .020

INSD 2009. Recensement General de La Population et de l'Habitation (RGPH) de 2006 analyse des resultats definitifs; theme 2 : etat et structure de la population, Ouagadougou, Burkina Faso, $181 \mathrm{p}$.
Kabore E, Sambare O, Ouedraogo A, Thiombiano A. 2013. Diversité et structure des cordons ripicoles le long de la sirba (Nord-Est du Burkina Faso). Int. J. Biol. Chem. Sci., 7(5) : 1929-1950, DOI:

http://dx.doi.org/10.4314/ijbcs.v7i5.13

Kadeba A, Nacoulma BMI, Ouedraogo A, Bachmann Y, Thiombiano A, Schmidt M, Boussim JI. 2015. Land cover change and plants diversity in the Sahel: A case study from northern Burkina Faso. Ann. For. Res., 58(1): 109-123. DOI: http://dx.doi.org/10.15287/afr.2015.350

Krebs JC. 1999. Ecological Methodology. Addison-Wesley Educational Publishers Inc. New York, USA.

Leroux L, Bégué A, Lo Seen D, Jolivot A, Kayitakire F. 2017. Driving forces of recent vegetation changes in the Sahel: Lessons learned from regional and local level analyses. Remote Sensing of Environment, 191: 38-54. DOI: https://doi.org/10.1016/j.rse.2017.01.014

Lykke AM, Kristensen MK, Ganaba S. 2004. Valuation of local use and dynamics of 56 woody species in the Sahel. Biodiversity and Conservation, 13: 1961-1990.

DOI: https://doi.org/10.1023/B:BIOC.000003 5876.39587.1a

Mahamat-Saleh M, Diallo A, Ousmane N, Faye MN, Guissé A. 2013. Caractérisation des peuplements ligneux de la zone Cayor Baol (Thiès-Sénégal). Int. J. Biol. Chem. Sci., 7(5) : 2117-2132. DOI: http://dx.doi.org/10.4314/ijbcs.v7i5.28

Mahamat-Saleh M, Ndiaye O, Diallo MD, Goy S, Niang K, Diallo A, Guissé A. 2015. Caractérisation des peuplements ligneux sur le tracé de la Grande Muraille Verte au Tchad. Int. J. Biol. Chem. Sci., 9 (5) : 2617-2627. DOI: http://dx.doi.org/10.4314/ijbcs.v9i5.31

Maranz S. 2009. Tree mortality in the African Sahel indicates an anthropogenic ecosystem displaced by climate change. Journal of Biogeography, 36(6): 11811193.

DOI: 
https://doi.org/10.1111/j.1365-

2699.2008.02081.x

Müller JV 2008. Grassland communities on a Sahelian peneplain in Burkina Faso. Feddes Repertorium, 119(1-2): 42-62. DOI:

https://doi.org/10.1002/fedr.200711141

Ndiaye O, Aly D, Bassimbé SM, Aliou G. 2013. Diversité floristique des peuplements ligneux du Ferlo, Sénégal. VertigO - La revue électronique en sciences de l'environnement, 13(3). DOI: http://id.erudit.org/iderudit/1026882ar

Neelo J, Teketay D, Kashe K, Masamba W. 2015. Stand structure, diversity and regeneration status of woody species in open and exclosed dry woodland sites around Molapo farming areas of the Okavango Delta, North eastern Botswana. Open Journal of Forestry, 5: 313-328.

DOI: http://dx.doi.org/10.4236/ojf.2015.54027

Ozer P, Hountondji YC, Niang AJ, Karimoune S, Manzo OL, Salmon M. 2010. Désertification au sahel : historique et perspectives. BSGLg, 54: 69-84.

DOI:

https://popups.uliege.be:443/07707576/index.php?id=942

Rasmussen K, D'haen S, Fensholt R, Fog B, Horion S, Nielsen JO, Rasmussen LV, Reenberg A. 2016. Environmental change in the Sahel: reconciling contrasting evidence and interpretations. Regional Environmental Change, 16(3): 673-680.

DOI:

https://doi.org/10.1007/s10113-0150778-1

Sacande M, Berrahmouni N. 2016. Community participation and ecological criteria for selecting species and restoring natural capital with native species in the Sahel. Restoration Ecology, 24(4): 479-488. DOI: http://onlinelibrary.wiley.com/doi/10.11 11/rec.12337/suppinfo

Sarr O, Diatta S, Gueye M, Ndiaye PM, Guisse A, Akpo LE. 2013. Importance des ligneux fourragers dans un système agropastoral au Sénégal (Afrique de l'ouest). Revue Méd. Vét., 164(1): 2-8.

Sinare H, Gordon LJ. 2015. Ecosystem services from woody vegetation on agricultural lands in Sudano-Sahelian West Africa. Agriculture, Ecosystems \& Environment, 200: 186-199. DOI: http://dx.doi.org/10.1016/j.agee.2014.11. 009

Sop TK, Oldeland J, Bognouno F, Schmiedel U, Thiombiano A. 2012. Ethnobotanical knowledge and valuation of woody plants species: a comparative analysis of three ethnic groups from the sub-Sahel of Burkina Faso. Environment, Development and Sustainability, 14(5): 627-649.

DOI: https://doi.org/10.1007/s10668-0129345-9

Sop TK, Oldeland J, Schmiedel U, Ouedraogo I, Thiombiano A. 2011. Population structure of three woody species in four ethnic domains of the Sub-Sahel of Burkina Faso. Land Degradation and Development, 22(6): 519 - 529. DOI: https://doi.org/10.1002/ldr.1026

Thiombiano A, Kampmann D. 2010. Atlas de la Biodiversité de l'Afrique de l'Ouest, Tome II : Burkina Faso. Ouagadougou \& Frankfurt/Main.Rep., 625 p.

Vincke C, Diédhiou I, Grouzis M. 2010. Long term dynamics and structure of woody vegetation in the Ferlo (Senegal). Journal of Arid Environments, 74: 268276.

DOI: https://doi.org/doi:10.1016/j.jaridenv.20 09.08.006

Wade TI, Ndiaye O, Mauclaire M, Mbaye B, Sagna M, Guisse A, Goffner D. 2018. Biodiversity field trials to inform reforestation and natural resource management strategies along the African Great Green Wall in Senegal. New Forests, 49(3): 341-362. DOI: https://doi.org/doi:10.1007/s11056-0179623-3. 